\title{
THE INFLUENCE OF EMOTIONAL INTELLIGENCE AND MOTIVATION TOWARDS STUDENT'S ENGLISH LEARNING ACHIEVEMENT \\ At state vocational high schools in karawang
}

\author{
Asep Darojatul Romli \\ Asep Jamaludin \\ Program of manajement study, Faculty of Business and Social Sciences \\ Buana Perjuangan Karawang University \\ asep.dj@ubpkarawang.co.id \\ asepjamaludin@ubpkarawang.ac.id
}

\begin{abstract}
The purpose of research is to know and explain the effect of emotional intelligence on motivation, to know and explain the effect of emotional intelligence on English learning achievement, to know and explain the influence of motivation ability on English learning achievement and to know and explain the influence of emotional intelligence on learning achievement English through motivation.

The research method used is survey method. Population in this research is all students of class $\mathrm{X}$ of first semester of SMKN 1 Karawang. The sampling technique used is cluster random sampling, the sample is taken randomly according to the class that has been formed. So, the sample in this study as many as 18 people from the total population of 192 people. The research instrument consists of three types of tests, namely the questionnaire of emotional intelligence, motivation questionnaire and English achievement test with the subject of the circle. Analysis of statistical data to test the hypothesis in this study using Path Analysis (Path Analysis). Statistic test is used t test.

The results showed: (1) direct influence of emotional intelligence on motivation, (2) direct influence of emotional intelligence on English learning achievement, (3) direct influence of emotional intelligence to English learning
\end{abstract}


achievement and (4) indirect effect of lateral thinking ability toward English learning achievement through creative thinking ability.

Keywords: Emotional Intelligence, Motivation and English learning achievement

\section{Introduction}

Education is the basic capital to build a developed nation. In this case, education plays a role to form cadres of the nation that qualified and able to compete in the era of globalization as it is today. To achieve this requires serious efforts from the government and all parties involved in the world of education in order to improve the quality of national education.

As one of the subjects tested on the national exam, English is still seen as a very difficult and boring subject for most learners. This is evidenced by the data achievement of English rapot grades in some schools in the district of Serang is less satisfactory.

Improving the quality of national education can be done if the students master minimum public knowledge. According to Suherman (2004: 60) minimum general knowledge that among them is English. English is a universal science underlying the development of modern technology and can be said as essentially all science, has an important role in various disciplines and advance the human mind power. English is taught at every level of education in Indonesia, from elementary to university level, therefore the government makes English as one of the subjects tested on the national exam.

Many factors influence student's learning achievement. One is the motivation and level of emotional intelligence of learners. Motivation is needed by learners in learning activities. Motivation to learn is the overall driving force within the self that leads to learning activities that ensure continuity of learning activities, so that the desired goal by the subject of learning can be achieved. Motivation is needed in English lessons, because with a high motivation students are able to solve problems in learning English. For example learners who have no motivation in him will tend to be lazy to learn, which in the end concentration in understanding the concept of English is not maximal.

198. Buana Ilmu 
Emotional intelligence is the ability of self to recognize the feelings of self and others and can manage it well so as to create a good relationship with others, especially in the learning activities. Emotional intelligence can also be interpreted as the ability to motivate yourself and survive frustration, controlling impulse and not exaggerating pleasure, regulating moods and keeping stress free does not cripple the ability to think, empathize and pray. this shows that the emotional intelligence of a student greatly affects the high low their motivation in learning.

\section{The formulation of a problem}

Based on the focus of the research above, the formulation of the problem in the study are: Is there a direct influence of emotional intelligence on students' English learning achievement. Is there a direct influence of motivation on student's english learning achievement. Is there a direct influence of emotional intelligence on motivation. Is there an indirect influence of emotional intelligence through motivation on student english learning achievement

\section{Literature review}

According to Azwar (2007: 157): "Learning achievement is an assessment that can be categorized into two approaches, that is, references to a criterion referenced evaluation. This should be remembered in the use of both approaches, it concerns the objectives and procedures for the preparation of items -item in the test concerned. "So the learning achievement is an assessment of the basis of the criteria or the provisions and assessments that essentially is to have the desired goal.

According to Kadir (2005: 233), "The achievement of learning English is one measure of the success rate of students after experiencing the learning process." The process of learning here is certainly learning English that can be measured in a certain period.

According to Gart, "Intelligence, includes at least the abilities demanded in the solution of the problems which require the comprehension and use of symbols" (Soemanto, 2006: 142). In Gart's definition it is emphasized that 
intelligence includes at least the ability necessary to solve problems that require understanding and use symbols. Still in Soemanto, Bischop an American psychologist says "Intelligence is the ability to solve problems of all kinds" which means intelligence (intelligence) is the ability to solve various types of problems. A person with a high intelligence level can solve problems more quickly.

emotional intelligence or so-called EQ / Emotional Quotient as proposed by Golemen in Aunurrahman (2009: 89) is the ability to motivate yourself and survive the frustration, control the impulse and not exaggerate the fun, set the mood and keep it free stress does not cripple the ability to think, empathize and pray.

Good and Brophy (1979: 36) define motivation as a hypothetical construct used to explain the execution of work, direction, intensity and accuracy in attitudes toward goals. The concept of motivation is closely related to motivation berprertasi (need for achievement), the desire for affiliation (need for affiliation), incentives (reward or punishment), habits (habit), discrepancies (discrepancy), anxiety.

\section{Research methods}

The research method used in this research is using survey. According to Margono (2009: 29), "the survey is a critical observation or investigation to get a clear and good light on a particular issue and within a particular area."

The purpose of the survey according to Margono (2009: 29) is "to get a picture that represents the area correctly." So in the process of this survey should take a representative sample data of the desired target population.

The design variables to be studied are as follows:

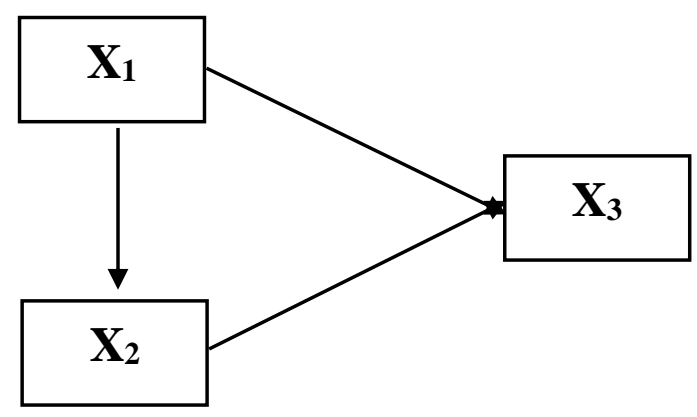

Design of Relationship Between Research Variables 
Information:

$\mathrm{X} 1=$ Emotional Intelligence

X2 = Motivation learning

X3 = English learning achievement

Survey on this research with Path Analysis or Path Analysis, which is looking for:

1. Direct Influence of Emotional Intelligence (X1) on Student Learning Achievement (X3)

2. The direct influence of learning motivation (X2) on students' English learning achievement (X3)

3. Direct Influence of Emotional Intelligence (X1) on Learning Motivation (X2)

4. The indirect effect of emotional intelligence (X1) through learning motivation (X2) on students' English learning achievement (X3)

\section{Research result}

Based on the research that the authors do, the object in this study is the students of class X semester I SMKN 1 Karawang, The characteristics of respondents are:

Have the average intelligence level. Open attitude and easy association with fellow students. Physically and mentally healthy. Average parental economic rate. Adequate learning facilities. Have a good mindset

The reason for selecting the characteristics of the respondents was in an attempt to obtain a homogeneous sample, since all members of the sample were totally selected from students who met these characteristics.

The results showed: (1) direct influence of emotional intelligence on motivation, (2) direct influence of emotional intelligence on learning achievement of English, (3) direct influence of emotional intelligence to English learning achievement and (4) indirect effect of lateral thinking ability toward English learning achievement through creative thinking ability. The t test for X1 to X3 (thitung $=2.441$ is bigger than ttable), $\mathrm{X} 2$ to $\mathrm{X} 3$ (tct $=2,246$ bigger than ttable), $\mathrm{X} 1$ to $\mathrm{X} 2$ (tcount $=3,382>$ bigger than ttable) and $\mathrm{X} 1$ to $\mathrm{X} 3$ via $\mathrm{X} 2$ thitung $=$ 0.336 is smaller than ttable), it shows the meaning that hypotheses 1, 2 and 3 have been proven whereas the fourth hypothesis is not proven. 


\section{Discussion}

Data descriptions of research results are grouped into three parts consisting of the dependent variable scores are English learning achievement (X3), free variable scores of emotional intelligence (X1) and free variable score that is motivation $(\mathrm{X} 2)$.

A. Respondent's Characteristic

Based on the research that the authors do, the object in this study is the students of class X semester I SMKN 1 Karawang, The characteristics of respondents are:

1. Have the average intelligence level

2. Open attitude and easy association with fellow students

3. Physically and mentally healthy

4. Average parental economic level

5. Adequate learning facilities

6. Have a good mindset

The reason for selecting the characteristics of the respondents was in an attempt to obtain a homogeneous sample, since all members of the sample were totally selected from students who met these characteristics.

B. A description of data

Data descriptions of research results are grouped into three parts consisting of the dependent variable scores are English learning achievement (X3), free variable scores of emotional intelligence (X1) and free variable score that is motivation (X2).

Description of Research Data

\begin{tabular}{|l|l|r|r|r|}
\hline \multicolumn{5}{|c|}{ Statistics } \\
\hline \multicolumn{2}{|c|}{} & $\begin{array}{c}\text { Emotional } \\
\text { Intelligence }\end{array}$ & Motivation & $\begin{array}{c}\text { Learning } \\
\text { achievement }\end{array}$ \\
\hline \multirow{2}{*}{ N } & Valid & 92 & 92 & 92 \\
\cline { 2 - 5 } & Missing & 0 & 0 & 0 \\
\hline
\end{tabular}




\begin{tabular}{|c|c|c|c|c|}
\hline \multicolumn{2}{|l|}{ Mean } & 82.88 & 72.85 & 61.52 \\
\hline \multicolumn{2}{|c|}{ Std. Error of Mean } & 1.074 & .771 & 1.146 \\
\hline \multicolumn{2}{|l|}{ Median } & 82.00 & 73.00 & 60.00 \\
\hline \multicolumn{2}{|l|}{ Mode } & 78 & 73 & 60 \\
\hline \multicolumn{2}{|c|}{ Std. Deviation } & 10.305 & 7.392 & 10.988 \\
\hline \multicolumn{2}{|l|}{ Variance } & 106.194 & 54.636 & 120.736 \\
\hline \multicolumn{2}{|l|}{ Range } & 55 & 41 & 50 \\
\hline \multicolumn{2}{|l|}{ Minimum } & 51 & 55 & 35 \\
\hline \multicolumn{2}{|l|}{ Maximum } & 106 & 96 & 85 \\
\hline \multicolumn{2}{|l|}{ Sum } & 7625 & 6702 & 5660 \\
\hline \multirow[t]{3}{*}{ Percentiles } & 25 & 77.25 & 67.25 & 55.00 \\
\hline & 50 & 82.00 & 73.00 & 60.00 \\
\hline & 75 & 87.75 & 76.00 & 70.00 \\
\hline
\end{tabular}

1. English learning achievement

Based on calculations with the help of SPSS 20.0 obtained the results of data processing as follows:

\section{Statistics}

Learning achievement

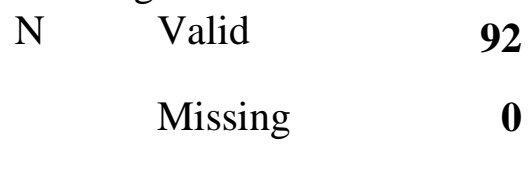

Mean

61.52

Std. Error of

Mean

1.146

Median

60.00

Mode

60

Std. Deviation

10.988

Variance

120.736

Range

50

Minimum

35

Maximum

85 


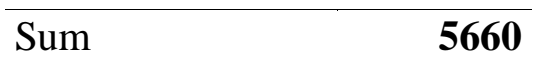

Based on the above table can be explained that the average score of English students' learning achievement has a value that is almost equal to the median value of 61.52 and 60. This shows that the student achievement score of English students in this study is quite representative.

The data contained in the table above also obtained a standard deviation score 10,988 which means that the difference in score of one respondent with other respondents has a 10.988 average value is quite large. Thus the variation of English student achievement data is quite strict and homogeneous.

Furthermore, with the help of SPSS 20.0 presented English learning achievement histogram, as follows:

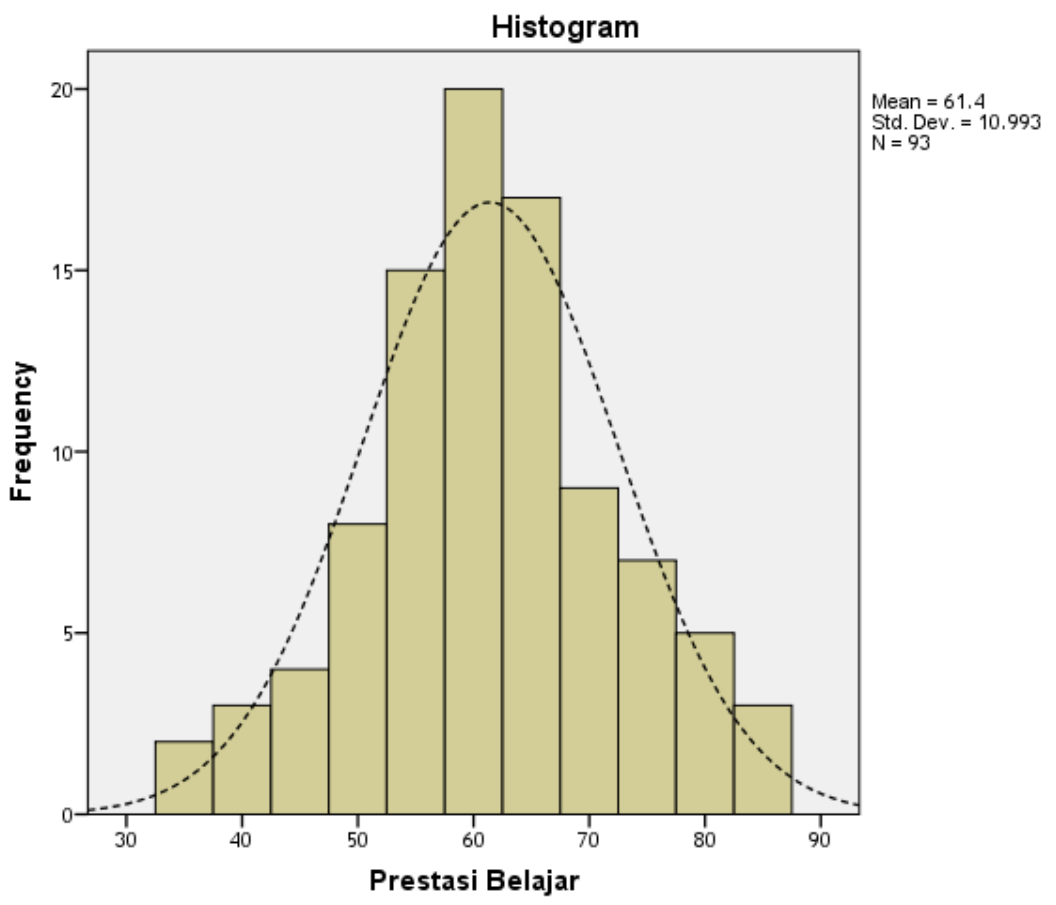

Histogram of student's english learning achievement of the program

From the histogram that has been displayed it can be seen and read clearly that the data being analyzed is quite good, because the curve is a symmetrical curve and this means having normal.

2. Emotional Intelligence

Based on calculations with the help of SPSS 20.0 obtained the results of data processing as follows: 


\begin{tabular}{|c|c|c|}
\hline \multicolumn{3}{|c|}{ Tabel } \\
\hline \multicolumn{3}{|c|}{ Statistics } \\
\hline \multicolumn{3}{|c|}{ Emotional Intelligence } \\
\hline \multirow[t]{2}{*}{$\mathrm{N}$} & Valid & 92 \\
\hline & Missing & 0 \\
\hline \multicolumn{2}{|c|}{ Mean } & 82.88 \\
\hline \multicolumn{3}{|c|}{$\begin{array}{l}\text { Std. Error } \\
\text { Mean }\end{array}$} \\
\hline \multicolumn{2}{|c|}{ Median } & 82.00 \\
\hline \multicolumn{2}{|c|}{ Mode } & 78 \\
\hline \multicolumn{2}{|c|}{ Std. Deviation } & 10.305 \\
\hline \multicolumn{2}{|c|}{ Variance } & 106.194 \\
\hline \multicolumn{2}{|c|}{ Range } & 55 \\
\hline \multicolumn{2}{|c|}{ Minimum } & 51 \\
\hline \multicolumn{2}{|c|}{ Maximum } & 106 \\
\hline \multicolumn{2}{|c|}{ Sum } & 7625 \\
\hline
\end{tabular}

Based on the above table can be explained that the average value of students' emotional intelligence has a value almost equal to the middle (median) of 82.88 and 82 . This shows that the emotional intelligence scores of students in this study is representative enough.

The data contained in the table above also obtained a standard deviation score of 10,305 which means that the difference in score of one respondent with other respondents has an average value of 10,305 is large enough. Thus the variation of students' emotional intelligence data is quite strict and homogeneous.

\section{Motivation}

Based on the calculation with the help of SPSS 20.0 obtained the results of data processing as follows: 


\begin{tabular}{lr}
\hline \multicolumn{2}{c}{ Tabel } \\
Statistics \\
Motivation \\
$\mathrm{N} \quad$ Valid & 92 \\
\multicolumn{1}{c}{ Missing } & 0 \\
Mean & 72.85 \\
Std. Error of & .771 \\
Mean & \\
Median & \\
Mode & 73.00 \\
Std. Deviation & 73 \\
Variance & 54.392 \\
Range & 41 \\
Minimum & 55 \\
Maximum & 96 \\
Sum & 6702 \\
\hline
\end{tabular}

\section{Conclusion}

Based on the results of research and conclusions that have been presented, the following are suggestions that can be put forward, namely:

1. Suggested to teacher of English lesson SMKN 1 Karawang, to continually strive to improve and develop the learning process of English teaching, so that student learning achievement of English student can be improved to be better again for the future.

2. Suggested to teachers of English lessons SMKN 1 Karawang to keep trying to instill and develop emotional intelligence and student motivation, so as to give a greater influence on the achievement of learning English in the future.

3. Suggested to the teacher of English lesson SMKN 1 Karawang to convey information about how to dig and develop emotional intelligence and maintain proper learning motivation to the students, so that students know, 
want to dig and develop it well and can improve learning achievement of English.

\section{References}

Arikunto, Suharsimi. 2006. Prosedur Penelitian Suatu Pendekatan Praktik.

Jakarta: Rineka Cipta.

Arikunto, Suharsimi. 2009. Dasar-dasar Pembuatan Instrumen Penelitian.

Jakarta: Rineka Cipta.

Margono, S. 2009. Metedologi Penelitian Pendidikan. Jakarta: Rineka Cipta.

Azwar. 2004. Intelegensi Anak. Jakarta : Balai Pustaka

Azwar. 2007. Tes Prestasi. Yogyakarta: Pustaka Belajar.

Good and Borphy. 1990. Educational Psychology, A Realistic Approach, London : Logman.

Kadir. 2005. Pengaruh Pendekatan Problem Possing Terhadap Prestasi

Belajar Bahasa Inggris Jenjang Pengetahuan, Pemahaman, Aplikasi dan

Evaluasi Ditinjau dari Metakognisi Siswa SMA di Jakarta. Jurnal

Pendidikan dan Kebudayaan, No.053, Hal. 230 - 250.

Soekamto, Toeti, 1998. Psikologi Pendidikan : Suatu Pendekatan Praktis, Jakarta :

Bina Aksara.

Aunurrahman. 2012. Belajar dan Pembelajaran. Bandung : Alfabeta

Atwater, Eastwood. 1990. Psychology of Adjustment Personal Growth in a Changing World, Fourth Edition, US : New Jersey 07632

Davies, Ivor K., 1981. Instruction Technique, USA : McGraw Hill.

McClelland, et al., 1976. The Achievement Motive, New York : AppletonCentury Crofts.

Purwanto, Ngalim. 2010. Psikologi Pendidikan. Bandung: PT. Remaja

Rosdakarya

Sudjana, Nana. 2001. Metoda Statistika. Bandung: Tarsito. 